\title{
Short Communication \\ Height and risk of prostate cancer in the prostate, lung, colorectal, and ovarian cancer screening trial
}

\section{J Ahn*,I,2, SC Moore', D Albanes', W-Y Huang', MF Leitzmann ${ }^{3}$ and RB Hayes ${ }^{2}$ for the Prostate, Lung, Colorectal, and Ovarian (PLCO) Cancer Screening Trial Project Team}

'Division of Cancer Epidemiology and Genetics, National Cancer Institute, NIH, DHHS, Bethesda, MD 20852, USA; ${ }^{2}$ Division of Epidemiology, New York University School of Medicine, New York, NY 100 16, USA; ${ }^{3}$ Department of Epidemiology and Preventive Medicine, University of Regensburg, Franz-JosefStrauss-Allee II, Regensburg D-93053, Germany

BACKGROUND: The relationship between prostate cancer and height is uncertain.

METHODS: We prospectively examined the association of height with prostate cancer among 34268 men in the prostate, lung, colorectal, and ovarian cancer trial. Anthropometry was assessed at baseline and 2 I 44 incident prostate cancer cases were identified upto 8.9 years of follow-up.

RESULTS: Overall, tallness was not associated with the risk of prostate cancer or with the risk of non-aggressive disease, but the risk for aggressive prostate cancer tended to be greater in taller men (Gleason score $\geqslant 7$ or stage $\geqslant$ III; $P$ trend $=0.05$; relative risk (RR) for $190 \mathrm{~cm}+$ vs $\leqslant 170 \mathrm{~cm}=1.39,95 \%$ confidence interval $(95 \% \mathrm{Cl}): 0.96-2.01)$. This association was largely limited to men below the age of 65 years $(P$ trend $=0.008$; RR for $190 \mathrm{~cm}+v s \leqslant 170 \mathrm{~cm}=1.76,95 \% \mathrm{Cl}: 1.06-2.93$; $P$ for interaction $=0.009)$, although the number of cases was small and risk estimates were somewhat unstable.

CONCLUSION: The results of this large prospective prostate cancer screening trial suggest that tallness is associated with increased risk for younger onset aggressive prostate cancer.

British Journal of Cancer (2009) I 0 I, 522-525. doi:10.1038/sj.bjc.6605 I59 www.bjcancer.com

Published online 30 June 2009

(c) 2009 Cancer Research UK

Keywords: height; prostate cancer; aggressiveness

Tallness is a potential risk factor for prostate cancer (Macinnis and English, 2006), possibly because of increased levels of bioavailable insulin-like growth factors (IGFs) or androgens (Tanner, 1990), or to genetic predisposition (Silventoinen et al, 2003). This association is supported by several, but not all, population-based studies, with a modest pooled effect size (relative risk $(R R)=1.09,95 \%$ confidence interval $(95 \% \mathrm{CI})=1.06-1.12$, per $10-\mathrm{cm}$ increase) based on 56 studies up to 2008 (Zuccolo et al, 2008). Since then, a large European cohort study (1500 cases; 129502 men) reported a null association $(\mathrm{RR}=1.01,95 \% \mathrm{CI}=0.98-1.04$ per 5 -cm increase) (Pischon et al, 2008). It is unclear whether the association between height and prostate cancer differs according to tumour characteristics or other risk factors. In the Prostate, Lung, Colorectal, and Ovarian (PLCO) Cancer Screening Trial, which has a standardised prostate cancer screening protocol, we examined the relationship of height with total prostate cancer, non-aggressive prostate cancer, and with aggressive prostate cancer.

\section{MATERIALS AND METHODS}

The PLCO Screening Trial is a multi-centre trial designed to evaluate screening methods for the early detection of these cancers

*Correspondence: Dr J Ahn, Division of Epidemiology, Department of Environmental Medicine, New York University School of Medicine, 650 First Ave, New York, NY 100 I6, USA; E-mail: Jiyoung.Ahn@NYUMC.org Received 24 March 2009; revised 29 May 2009; accepted 5 June 2009; published online 30 June 2009
(Prorok et al, 2000). Briefly, more than 75000 men, aged 55-74 years, were recruited from 10 centres between 1993 and 2001 and randomised to receive either annual prostate screening (serum prostate-specific antigen (PSA) testing and digital rectal examination (DRE)) or standard care. Participants completed a risk factor questionnaire at baseline, which included current weight and height. The study was approved by the institutional review boards at the National Cancer Institute and the screening centres, and all participants provided informed consent.

Of the 38349 men who were randomly assigned to the screening arm of the trial, we excluded men who reported a history of cancer other than non-melanoma skin cancer $(n=775)$; men without an initial PSA test or DRE $(n=2470)$; men who received an initial screening examination, but with whom there was no subsequent contact $(n=721)$; men who did not complete the baseline questionnaire $(n=898)$; and men with missing $(n=205)$ or extreme values for height $(n=12 ;<150 \mathrm{~cm})$. We also excluded men whose initial screening examination occurred after 30 September 2002, the censoring date for this analysis $(n=72)$. After exclusions, the analytic cohort comprised 34268 men (some participants were included in more than one exclusion category).

For men with suspected prostate cancer from cancer screening or for those who reported prostate cancer on their annual followup questionnaire, we requested medical records to confirm the diagnosis and to obtain TNM stage and grade information. We used death certificates, autopsy reports, and supporting medical/ pathological records to confirm diagnosis, stage, and grade for the deceased participants. Only histologically confirmed cases were included in the analysis. Prostate cancers were defined as non- 
aggressive if classified as stage I or II (localised disease) and had a Gleason sum of $<7$ (low-grade disease). Tumours were considered aggressive if classified as stage III or IV (high-stage disease) or assigned a Gleason sum of $\geqslant 7$ (high grade-disease). We also distinguished between high-grade disease (defined as a Gleason sum of $\geqslant 7$ ) and high-stage disease (defined as stage III or IV).

Person-years were calculated from the date of the baseline prostate cancer screening to the date of the most recently completed annual follow-up questionnaire, date of diagnosis, death, or 30 September 2002, whichever came first. We used Cox proportional hazards regression analysis to estimate RRs and $95 \%$ CIs. Multivariable analyses were adjusted for confounding factors, including age (continuous), race (White, Black, Asian/Pacific Islander, other), PLCO study centre, family history of prostate cancer (first degree; yes, no, missing), smoking status (never, current, former, pipe-cigar only), education ( $<12$ years, 12 years of high school, post high school or college, and college graduation or more), history of diabetes (yes, no, missing), body mass index (BMI) $\left(18.5-24.9,25.0-29.9,30.0 \mathrm{~kg} / \mathrm{m}^{2}\right.$ or more), and number of screenings using PSA or DRE during the trial. Tests for linear trend were conducted by assigning the median value for each category and treating that term as a single continuous variable in the model. In addition, stratified analyses were carried out on the basis of age at baseline, history of prostate cancer, race, history of diabetes, current BMI, and BMI at age 18 years. We formally tested for interactions using log-likelihood ratio tests. All the analyses were conducted using SAS version 9.1 (SAS Institute Inc., Cary, NC, USA). All $P$-values were two sided.

\section{RESULTS}

Taller men were more likely to be Caucasian or African American, to have a positive family history of prostate cancer, to smoke, and to consume more total energy than shorter men (Table 1). Other characteristics, including the frequency of prostate cancer screenings during the trial, did not vary appreciably by height.

During 170882 person-years of follow-up of 34268 men, 2144 men were diagnosed with prostate cancer, of whom 1202 (57\%) were classified as non-aggressive and 912 (43\%) as aggressive cases. In multivariable analysis, height was associated neither with the risk of prostate cancer overall nor with non-aggressive disease (Table 2). However, the risk for aggressive prostate cancer tended to be greater in taller men, with risk increasing in a dose-response manner (Gleason score $\geqslant 7$ or stages $\geqslant$ III; $P$ trend $=0.05 ; \mathrm{RR}=1.39,95 \% \mathrm{CI}=0.96-2.01$; comparing $190+$ with $\leqslant 170 \mathrm{~cm}$ ). Positive trends with height were noted for both high-grade (Gleason score $\geqslant 7$ only; $P$ trend $=0.04$ ) and high-stage disease (stages $\geqslant$ III only; $P$ trend $=0.06$ ).

As exploratory analyses, we have examined whether relationships with height differ according to prostate cancer risk factors. A strong positive association with aggressive disease was observed for men younger than 65 years $(P$ trend $=0.008$; RR $=1.76,95 \%$ $\mathrm{CI}=1.06-2.93$; comparing $190+$ with $\leqslant 170 \mathrm{~cm})$. No clear pattern was observed for men in the older ( $\geqslant 65$ years) age group. The test for interaction between age and height was statistically significant $(P$ interaction $=0.009)$. There was no interaction between height and other risk factors (i.e., race, diabetes, current BMI, or BMI at age 18 years) in relation to risk (all $P$ interactions $>0.05$; data not shown).

\section{DISCUSSION}

In this large prospective study, we found that height was associated with increased risk of aggressive prostate cancer in individuals below the age of 65 years. As all participants in this screening trial were screened annually using both PSA testing and DRE for the

Table I Baseline characteristics of participants according to height, PLCO study ${ }^{\mathrm{a}}$

\begin{tabular}{|c|c|c|c|c|c|c|}
\hline \multirow[b]{2}{*}{ Characteristic } & \multicolumn{6}{|c|}{ Height (cm) } \\
\hline & $\leqslant \mathbf{1 7 0}$ & $|7|-\mid 74.9$ & $175-179.9$ & $180-184.9$ & $185-189.9$ & $190+$ \\
\hline Number of participants, n (\%) & $3472(10.1)$ & $6472(18.9)$ & $9804(28.6)$ & $8773(25.6)$ & $4276(12.5)$ & $|47|(4.3)$ \\
\hline Age, years & 63.4 & 63.1 & 62.7 & 62.3 & 61.9 & 61.7 \\
\hline \multicolumn{7}{|l|}{ Race, \% } \\
\hline White & 66.3 & 85.0 & 91.9 & 93.3 & 94.0 & 91.7 \\
\hline Black & 4.8 & 4.0 & 4.0 & 4.4 & 4.7 & 6.5 \\
\hline Others & 28.9 & || & 4.1 & 2.3 & 1.3 & 1.8 \\
\hline Family history of prostate cancer, $\%$ & 7.2 & 7.6 & 7.2 & 7.5 & 8.3 & 8.7 \\
\hline History of diabetes, $\%$ & 9.9 & 10.5 & 8.4 & 9.1 & 8.0 & 10.3 \\
\hline Daily aspirin use, \% & 29.3 & 30.9 & 30.5 & 30.7 & 29.6 & 28.9 \\
\hline \multicolumn{7}{|l|}{ Smoking status, \% } \\
\hline Never & 32.2 & 29.5 & 29.1 & 29.0 & 28.3 & 28.2 \\
\hline Current & 10.2 & 11.2 & 11.0 & 11.4 & 11.7 & 10.9 \\
\hline Former & 50.1 & 51.4 & 52.1 & 51.8 & 51.9 & 52.3 \\
\hline Cigar or pipe only & 7.5 & 7.9 & 7.9 & 7.8 & 8.2 & 8.6 \\
\hline Physical activity, h per week & 1.9 & 2.0 & 2.0 & 2.0 & 2.0 & 2.0 \\
\hline Total energy, kcal per day & 2184 & 2280 & 2352 & 2412 & 2503 & 2589 \\
\hline Current BMI, $\mathrm{kg} \mathrm{m}^{-2}$ & 27.4 & 27.5 & 27.6 & 27.6 & 27.6 & 27.5 \\
\hline $\mathrm{BMl}$ at age $20, \mathrm{~kg} \mathrm{~m}^{-2}$ & 23.0 & 22.9 & 23.0 & 23.0 & 22.9 & 22.6 \\
\hline PSA (baseline), $\mathrm{ng} \mathrm{ml}^{-1}$ & 2.4 & 1.8 & 1.8 & 1.9 & 2.2 & 1.7 \\
\hline DRE (baseline), $\%$ & 6.7 & 7.6 & 8.1 & 7.4 & 7.3 & 6.1 \\
\hline Biopsy (before study participation), \% & 4.5 & 4.0 & 4.3 & 4.4 & 4.0 & 3.9 \\
\hline No. of screens per year ${ }^{b}$ & 0.8 & 0.8 & 0.8 & 0.8 & 0.8 & 0.8 \\
\hline
\end{tabular}

$\mathrm{BMI}=$ body mass index; DRE = digital rectal examination; PLCO = Prostate, Lung, Colorectal, and Ovarian; PSA = prostate-specific antigen. ${ }^{\mathrm{M}}$ Means or proportions,

${ }^{b}$ Average number of prostate cancer screening examinations (PSA test and/or DRE) during the period of active screening (years: $0-5$ ). 
Table 2 Multivariate relative risks (RR) and 95\% confidence intervals (Cls) of prostate cancer in relation to height, PLCO study

\begin{tabular}{|c|c|c|c|c|c|c|c|c|}
\hline Height (cm) & $\leqslant 170$ & | 7 | - | 74.9 & | $75-179.9$ & $|80-| 84.9$ & $|85-| 89.9$ & $190+$ & $5 \mathrm{~cm}$ increment & $P$ trend \\
\hline \multicolumn{9}{|l|}{ Total study population } \\
\hline No. total cases & 202 & 387 & 619 & 570 & 275 & 91 & & \\
\hline $\mathrm{RR}(95 \% \mathrm{Cl})^{\mathrm{a}}$ & 1.00 (ref) & $1.06(0.89-1.26)$ & $1.07(0.9 \mid-1.26)$ & $1.14(0.96-1.34)$ & $1.10(0.91-1.33)$ & $1.06(0.82-1.36)$ & $1.02(0.98-1.05)$ & 0.28 \\
\hline No. non-aggressive cases ${ }^{b}$ & 110 & 212 & 358 & 331 & 148 & 43 & & \\
\hline $\operatorname{RR}(95 \% \mathrm{Cl})^{\mathrm{a}}$ & 1.00 (ref) & $1.04(0.82-\mid .31)$ & $1.09(0.87-1.35)$ & $1.16(0.93-1.46)$ & $1.04(0.8 \mid-1.35)$ & $0.88(0.61-1.26)$ & $1.00(0.96-1.05)$ & 0.92 \\
\hline No. aggressive cases ${ }^{b}$ & 84 & 170 & 255 & 232 & 125 & 46 & & \\
\hline $\operatorname{RR}(95 \% \mathrm{Cl})^{\mathrm{a}}$ & 1.00 (ref) & $1.17(0.90-1.53)$ & $1.14(0.88-1.48)$ & $1.19(0.9|-| .54)$ & $1.29(0.97-1.73)$ & $1.39(0.96-2.01)$ & $1.05(1.00-1.10)$ & 0.05 \\
\hline \multicolumn{9}{|l|}{ Age $<65$ years } \\
\hline No. aggressive cases ${ }^{b}$ & 32 & 69 & 119 & 128 & 68 & 30 & & \\
\hline $\operatorname{RR}(95 \% \mathrm{Cl})^{\mathrm{a}}$ & 1.00 (ref) & $1.17(0.76-1.78)$ & $1.23(0.82-1.84)$ & $1.38(0.93-2.06)$ & $1.47(0.95-2.26)$ & $1.76(1.06-2.93)$ & $1.08(1.01-1.15)$ & 0.008 \\
\hline \multicolumn{9}{|l|}{ Age $\geqslant 65$ years } \\
\hline No. aggressive cases ${ }^{b}$ & 52 & $10 \mid$ & 136 & 104 & 56 & 16 & & \\
\hline $\mathrm{RR}(95 \% \mathrm{Cl})^{\mathrm{a}}$ & 1.00 (ref) & $1.20(0.85-1.70)$ & $1.08(0.77-1.52)$ & $1.02(0.72-1.46)$ & $1.16(0.78-1.72)$ & $1.09(0.62-1.95)$ & $1.01(0.95-1.09)$ & 0.88 \\
\hline
\end{tabular}

first 5 years on study, our findings are not likely to be due to differential cancer detection according to height. As all prostate cancers were evaluated uniformly for stage and grade by biopsy, the possibility of misclassification of cases was also minimal.

More than 30 prospective and 27 case-control studies have examined height and overall prostate cancer risk (Macinnis and English, 2006; Zuccolo et al, 2008), but findings are mixed; some studies showed a positive association (Le Marchand et al, 1994; Andersson et al, 1997; Giovannucci et al, 1997; Hebert et al, 1997; Rodriguez et al, 2001; Engeland et al, 2003; Cox et al, 2006; Sequoia et al, 2006; Zuccolo et al, 2008), whereas others found no relation (Severson et al, 1988; Cerhan et al, 1997; Veierod et al, 1997; Nilsen and Vatten, 1999; Clarke and Whittemore, 2000; Pischon et al, 2008). Stronger associations were observed for more advanced or fatal prostate cancer among 7 (Andersson et al, 1997; Giovannucci et al, 1997, 2004; Rodriguez et al, 2001; Cox et al, 2006; Sequoia et al, 2006; Zuccolo et al, 2008) of the 14 (Le Marchand et al, 1994; Andersson et al, 1997; Giovannucci et al, 1997, 2004; Nilsen and Vatten, 1999; Habel et al, 2000; Hsing et al, 2000; Norrish et al, 2000; Rodriguez et al, 2001; Macinnis et al, 2003; Cox et al, 2006; Sequoia et al, 2006; Pischon et al, 2008; Zuccolo et al, 2008) studies that included analyses for advanced or fatal prostate cancers. Consistent with our findings, a recent meta-analysis reported that the pooled estimate for aggressive or fatal prostate cancer was slightly higher than for all prostate cancers (RR for advanced or fatal prostate cancer $=1.12,95 \% \mathrm{CI}=1.05-1.19$, per $10-\mathrm{cm}$ increase in height) (Macinnis and English, 2006; Zuccolo et al, 2008); however, the meta-analysis showed marked between-study heterogeneity $\left(I^{2}=47 \%\right)$ (Zuccolo et al, 2008).

Our finding of a stronger association with younger onset aggressive prostate cancer is consistent with a prospective study in Hawaii ( $<72.5$ years, $n=31$ cases) (Le Marchand et al, 1994), but numbers were small and risk estimates unstable. No other study has reported on the height-prostate cancer relationship according to age. Two studies reported somewhat stronger associations with advanced/aggressive disease in men with a positive family history of prostate cancer (Norrish et al, 2000; Ahn et al, 2008). The limited numbers of aggressive cases with a first-degree family

\section{REFERENCES}

Ahn J, Moslehi R, Weinstein SJ, Snyder K, Virtamo J, Albanes D (2008) Family history of prostate cancer and prostate cancer risk in the Alpha- history $(n=109)$, prevented our examining potential interaction with family history. Our findings require confirmation in large consortium-based studies.

Height is influenced by bioavailable IGFs and androgens (Tanner, 1990). Insulin-like growth factors (Roddam et al, 2008) and androgens (Henderson et al, 2003) have been implicated in prostate cancer, thus providing a biologically plausible link with height. However, the reasons for stronger associations with height in aggressive disease among younger than older men are not clear. Further biochemical studies investigating the underlying potential biological mechanisms are warranted.

A limitation of our study is that height was assessed by self-report and hence was not validated. Nevertheless, the correlations between measured and self-reported height are typically high, ranging from 0.80 to 0.95 (Willett, 1998), although men tend to overreport their height (Spencer et al, 2002); which could have attenuated estimates of effect toward the null. Advantages of this study include its large size, prospective design, and reasonably detailed anthropometry data with a substantial range in height levels. This enabled us to examine the risk of prostate cancer according to narrow height categories across numerous potentially important effect modifiers.

This large prospective study suggests that tallness may be associated with increased risk of aggressive prostate cancer, particularly in younger men; confirmation is needed in other populations.

\section{ACKNOWLEDGEMENTS}

This research was supported by contracts from the Division of Cancer Prevention, National Cancer Institute, NIH, DHHS. The authors thank Drs. Christine Berg and Philip Prorok, Division of Cancer Prevention, National Cancer Institute, the Screening Center investigators and the staff of the Prostate, Lung, Colorectal, and Ovarian (PLCO) Cancer Screening Trial, Mr Tom Riley and staff, Information Management Services, Inc., Ms Barbara O'Brien and staff, Westat, Inc. Most importantly, we acknowledge the study participants for their contributions to making this study possible. 
Andersson SO, Wolk A, Bergstrom R, Adami HO, Engholm G, Englund A, Nyren O (1997) Body size and prostate cancer: a 20-year follow-up study among 135006 Swedish construction workers. J Natl Cancer Inst 89: $385-389$

Cerhan JR, Torner JC, Lynch CF, Rubenstein LM, Lemke JH, Cohen MB, Lubaroff DM, Wallace RB (1997) Association of smoking, body mass, and physical activity with risk of prostate cancer in the Iowa 65+ Rural Health Study (United States). Cancer Causes Control 8: 229-238

Clarke G, Whittemore AS (2000) Prostate cancer risk in relation to anthropometry and physical activity: the National Health and Nutrition Examination Survey I Epidemiological Follow-Up Study. Cancer Epidemiol Biomarkers Prev 9: 875-881

Cox B, Sneyd MJ, Paul C, Skegg DC (2006) Risk factors for prostate cancer: a national case-control study. Int J Cancer 119: 1690 - 1694

Engeland A, Tretli S, Bjorge T (2003) Height, body mass index, and prostate cancer: a follow-up of 950000 Norwegian men. Br J Cancer 89: $1237-1242$

Giovannucci E, Rimm EB, Liu Y, Willett WC (2004) Height, predictors of C-peptide and cancer risk in men. Int J Epidemiol 33: 217-225

Giovannucci E, Rimm EB, Stampfer MJ, Colditz GA, Willett WC (1997) Height, body weight, and risk of prostate cancer. Cancer Epidemiol Biomarkers Prev 6: $557-563$

Habel LA, Van Den Eeden SK, Friedman GD (2000) Body size, age at shaving initiation, and prostate cancer in a large, multiracial cohort. Prostate 43: $136-143$

Hebert PR, Ajani U, Cook NR, Lee IM, Chan KS, Hennekens CH (1997) Adult height and incidence of cancer in male physicians (United States). Cancer Causes Control 8: 591-597

Henderson BE, Ponder B, Ross RK (2003) Hormones, Genes, and Cancer. Oxford University Press: New York, NY

Hsing AW, Deng J, Sesterhenn IA, Mostofi FK, Stanczyk FZ, Benichou J, Xie T, Gao YT (2000) Body size and prostate cancer: a populationbased case-control study in China. Cancer Epidemiol Biomarkers Prev 9: $1335-1341$

Le Marchand L, Kolonel LN, Wilkens LR, Myers BC, Hirohata T (1994) Animal fat consumption and prostate cancer: a prospective study in Hawaii. Epidemiology 5: 276-282

Macinnis RJ, English DR (2006) Body size and composition and prostate cancer risk: systematic review and meta-regression analysis. Cancer Causes Control 17: 989-1003

Macinnis RJ, English DR, Gertig DM, Hopper JL, Giles GG (2003) Body size and composition and prostate cancer risk. Cancer Epidemiol Biomarkers Prev 12: 1417 - 1421

Nilsen TI, Vatten LJ (1999) Anthropometry and prostate cancer risk: a prospective study of 22,248 Norwegian men. Cancer Causes Control 10: 269-275

Norrish AE, McRae CU, Holdaway IM, Jackson RT (2000) Height-related risk factors for prostate cancer. Br J Cancer 82: $241-245$

Pischon T, Boeing H, Weikert S, Allen N, Key T, Johnsen NF, Tjonneland A, Severinsen MT, Overvad K, Rohrmann S, Kaaks R, Trichopoulou A, Zoi G, Trichopoulos D, Pala V, Palli D, Tumino R, Sacerdote C, Bueno-
de-Mesquita HB, May A, Manjer J, Wallstrom P, Stattin P, Hallmans G, Buckland G, Larranaga N, Chirlaque MD, Martinez C, Redondo Cornejo ML, Ardanaz E, Bingham S, Khaw KT, Rinaldi S, Slimani N, Jenab M, Riboli E (2008) Body size and risk of prostate cancer in the European prospective investigation into cancer and nutrition. Cancer Epidemiol Biomarkers Prev 17: 3252 - 3261

Prorok PC, Andriole GL, Bresalier RS, Buys SS, Chia D, Crawford ED, Fogel R, Gelmann EP, Gilbert F, Hasson MA, Hayes RB, Johnson CC, Mandel JS, Oberman A, O'Brien B, Oken MM, Rafla S, Reding D, Rutt W, Weissfeld JL, Yokochi L, Gohagan JK (2000) Design of the prostate, lung, colorectal and Ovarian (PLCO) cancer screening trial. Control Clin Trials 21: $273 \mathrm{~S}-309 \mathrm{~S}$

Roddam AW, Allen NE, Appleby P, Key TJ, Ferrucci L, Carter HB, Metter EJ, Chen C, Weiss NS, Fitzpatrick A, Hsing AW, Lacey Jr JV, Helzlsouer K, Rinaldi S, Riboli E, Kaaks R, Janssen JA, Wildhagen MF, Schroder FH, Platz EA, Pollak M, Giovannucci E, Schaefer C, Quesenberry Jr CP, Vogelman JH, Severi G, English DR, Giles GG, Stattin P, Hallmans G, Johansson M, Chan JM, Gann P, Oliver SE, Holly JM, Donovan J, Meyer F, Bairati I, Galan P (2008) Insulin-like growth factors, their binding proteins, and prostate cancer risk: analysis of individual patient data from 12 prospective studies. Ann Intern Med 149: 461-468

Rodriguez C, Patel AV, Calle EE, Jacobs EJ, Chao A, Thun MJ (2001) Body mass index, height, and prostate cancer mortality in two large cohorts of adult men in the United States. Cancer Epidemiol Biomarkers Prev 10: $345-353$

Sequoia JS, Wright ME, McCarron P, Pietinen P, Taylor PR, Virtamo J, Albanes D (2006) A prospective investigation of height and prostate cancer risk. Cancer Epidemiol Biomarkers Prev 15: 2174-2178

Severson RK, Grove JS, Nomura AM, Stemmermann GN (1988) Body mass and prostatic cancer: a prospective study. BMJ 297: 713-715

Silventoinen K, Sammalisto S, Perola M, Boomsma DI, Cornes BK, Davis C, Dunkel L, De Lange M, Harris JR, Hjelmborg JV, Luciano M, Martin NG, Mortensen J, Nistico L, Pedersen NL, Skytthe A, Spector TD, Stazi MA, Willemsen G, Kaprio J (2003) Heritability of adult body height: a comparative study of twin cohorts in eight countries. Twin Res 6: $399-408$

Spencer EA, Appleby PN, Davey GK, Key TJ (2002) Validity of self-reported height and weight in 4808 EPIC-Oxford participants. Public Health Nutr 5: $561-565$

Tanner JM (1990) Foetus into Man. Physical Growth from Conception to Maturity. Harvard University Press: Cambridge

Veierod MB, Laake P, Thelle DS (1997) Dietary fat intake and risk of prostate cancer: a prospective study of 25,708 Norwegian men. Int $J$ Cancer 73: $634-638$

Willett W (1998) Nutritional Epidemiology. Oxford University Press: New York, NY

Zuccolo L, Harris R, Gunnell D, Oliver S, Lane JA, Davis M, Donovan J, Neal D, Hamdy F, Beynon R, Savovic J, Martin RM (2008) Height and prostate cancer risk: a large nested case-control study (ProtecT) and meta-analysis. Cancer Epidemiol Biomarkers Prev 17: 2325-2336 